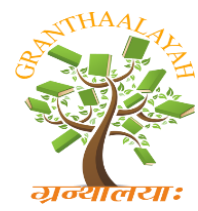

INTERNATIONAL JOURNAL OF RESEARCH GRANTHAALAYAH

A knowledge Repository

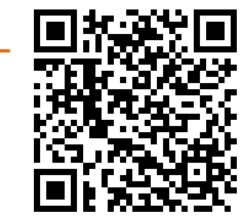

Social

\title{
A STUDY ON CORPORAL PUNISHMENT IN SCHOOLS AT SIVAKASI
}

\author{
R. Kalaivani * ${ }^{*}$ \\ *1 Assistant Professor of History, The Standard Fireworks Rajarathnam College for Women, \\ Sivakasi Virudhunagar District, Tamil Nadu, INDIA
}

\begin{abstract}
Corporal punishment has been classified as an act of violence and abuse on children. Strictly defined 'corporal punishment' is the infliction of pain intended to change a person's behaviour or to punish them. Though it mainly refers to physical pain either through hitting or forcing the child to sit/stand in uncomfortable positions; an evolving definition also includes within its ambit wrongful confinement, verbal insults, threats and humiliation, which are used with impunity and in utter disregard to the law of land and principles of learning. Children due to fear are often silent and submit to violence without questioning. They sometimes show signs of deep hurt in their behavior but this often goes unnoticed, perpetuating further violence on them. Corporal punishment not only affects the emotional behaviour and academic performance of a child, but also leads to reduction in self-esteem and dignity of child.
\end{abstract}

Keywords:

Corporal punishment, Child, Violence, Behaviour.

Cite This Article: R. Kalaivani, “A STUDY ON CORPORAL PUNISHMENT IN SCHOOLS AT SIVAKASI” International Journal of Research - Granthaalayah, Vol. 4, No. 2 (2016): 31-38.

\section{INTRODUCTION}

"The birth of every child bring the good news that God is pleased with the Human Beings"

-Tagore

The concept of Human Rights is an ethical concept which has developed throughout the history as a result of negative conditions (War, Slavery, Oppression, Poverty etc) that befell humanity. In India the beginning of the Human Rights can be traced back to the old smriti and the Mahabaratha's ideal of welfare state, which recommended freedom from fear and freedom from want for all. The basis of the struggle led from Mahatma Gandhi's struggle in South Africa against that country's policy of racial discrimination, was also for the Protection of basic Human Rights. After the First World War League of Nations came into force in 1919.But this Organization gave much importance to Peace \& Security. Within the League of Nations International Labour Organization was formed. It raised voice for worker's rights. After the 
Second World War with the help of United Nations through UN charter in 1945, United Nations Organizations was formed at New York, U.S.A. It gave importance to Human Rights.

Childhood is a unique and critical stage of life. All children share the same basic needs for safety, health, nurturance and dignity. Every child has a dream. This is the stage where the child like the butterfly flies away, this is the age of flying, singing nursery rhymes, dancing, meeting and mingling with others of the peer group.

\section{CORPORAL PUNISHMENT}

Every day in the world, children are beaten in their schools as a means of discipline. Corporal Punishment means to inflict punishment on the body. It is to beat, hit, spank, swat, pinch or cane a child with belts, hands, sticks or any other tool. Such violence may be a deliberate act of punishment or simply the impulsive reaction of an irritated teacher, parent, adult or even an older child. No matter what form the violence however, it is always a violation of children's fundamental human rights. Corporal Punishment can be defined as a painful, intentionally inflicted physical penalty, administered by a person in authority for disciplinary purposes. Corporal Punishment can occur anywhere, and whippings, beatings, paddlings and flogging are specific forms of Corporal Punishment.

According to law encyclopedia Corporal Punishment means "Physical punishment, as distinguished from pecuniary punishment or a fine; any kind of punishment inflicted on the body. Corporal punishment arises in two main contexts.

- As a method of discipline in schools and

- As a form of punishment for committing a crime.

\section{ORIGIN OF CORPORAL PUNISHMENT}

Early Babylonian law developed the principle of lextalionis, which asserted that criminals should receive as precisely those injuries they had inflicted upon their victims. Many subsequent societies applied this "eye for an eye tooth for a tooth" principle quite literally in dealing with offenders. From ancient times through the $18^{\text {th }}$ century, corporal punishment was commonly used in those instances that did not call for the death penalty or for exile or transportation. But the growth of humanitarian ideals during the enlightment and afterward led to the gradual abandonment of corporal punishment, and by the later $20^{\text {th }}$ century it had been almost entirely replaced by imprisonment or other non-violent penalties. Corporal punishment implies the use of physical force at a school to impose discipline amongst school children but this is not considered to be a good way to impose punishment as it undermines the dignity of the child. The use of physical force upon children can be quite dangerous as it may have psychological problems on the children. It needs to be taken a serious note to put an end to corporal punishment in every school. 


\section{KINDS OF PUNISHMENTS IN SCHOOLS}

\section{PHYSICAL PUNISHMENTS}

The following are the types of physical punishments practiced in schools

- Making the children stand as a wall chair (Goda Kurchee in Telugu)

- Keeping the school bags on their heads

- Making them stand for the whole day in the sun

- Make the children kneel down and do the work and then enter the classroom

- Making them stand on the bench

- Making them raise hands

- Hold a pencil in their mouth and stand

- Holding their ears with hands passed under the legs

- Tying of the children's hands

- Making them to do sit-ups (Gunjeelu)

- Caning and Pinching and

- Twisting the ears (Chevulu Pindadam)

\section{EMOTIONAL PUNISHMENTS}

The following are the types of emotional punishments practiced in schools

- Slapping by the opposite sex.

- Scolding, abusing and humiliating.

- Label the child according to his or her misbehavior and send him or her around the school.

- Make them stand on the back of the class and to complete the work.

- Suspending them for a couple of days.

- Pinning paper on their back and labeling them "I am a fool", "I am a donkey" etc.

- Teacher takes the child to every class she goes and humiliates the child.

- Removing the shirts of the boys.

\section{NEGATIVE REINFORCEMENT}

The following are the types of negative reinforcement practiced in schools

- Detention during the break and lunch

- Locking them in a dark room

- Call for parents or asking the children to bring explanatory letters from the parents

- Sending home or keeping the children outside the gate.

- Making the children sit on the floor in the classroom.

- Making the child clean the premises.

- Making the child run around the building or in the playground

- Sending the children to Institutional Head. 
- Making them to teach in the class.

- Making them to stand till the teacher comes.

- Threaten to issue Transfer Certificate for the child.

- Asking them to miss games or other activities.

- Deducting marks.

- Treating the three late comings equal to one absent.

- Giving excessive imposition.

- Make the children pay fines.

- Not allowing them enters class.

- Sitting on the floor for one period, day, week and month.

- Placing black marks on their disciplinary charts.

- Giving oral warnings in the diary or calendar.

Apart from these punishments, there were two more types that is

\section{SPECIAL PUNISHMENTS}

- A school invented another imaginative method of getting the boy beaten up by girl studying in lower class.

- In another type the teacher takes the wrongdoing child along with him or her to each class of different year as per schedule to further inflict insult.

- While a school teacher prevents a girl from eating from her lunch box.

\section{NORMAL RANGE OF PUNISHMENTS}

- Wall chairs (sitting as if on the chair without anyone against the wall for half an- hour to one hour) wall chairs plus a school bag on the head or thighs which cause more physical pain.

- Writing impositions for more than fifty times within a short time, which is physically not possible to complete is a new type of punishment. If an English medium student talks in Tamil he or she will be made to write, "I will not speak in Tamil" for fifty to hundred times, a mental punishment too.

\section{REASONS FOR CORPORAL PUNISHMENT}

- The lack of accountability towards children in schools is important factor that contributes to violence in schools and to teachers making use of corporal punishment.

- Crowded classrooms with inadequate infrastructure, insufficient learning tools also contribute to increased stress among teachers and subsequently to the frequent use of corporal punishment.

- Teachers are frequently poorly trained, underpaid and undervalued it lead to use of corporal punishment.

- Moreover many parents also ask teachers to beat their children, and teachers are frequently parents themselves, who may beat their own children. 
- The main criteria for teacher supervision / evaluation systems is based on whether the curriculum has been completed and how many of the students score 'good' marks in the final exams..... Failure to perform better than others in regular class work, home work and tests, under a system which is obsessed with ranking, invites frequent and systematic physical and emotional violence.

\section{EFFECTS OF CORPORAL PUNISHMENT}

Corporal punishment leads to negative attitude among children.

- Beyond violating a fundamental right of the child causes pain, injury, humiliation, anxiety, anger, hatred and vindictiveness that could have long-term psychological effects.

- Children subjected to repeated violence may exhibit dysfunctional behaviour such as poor communication and they may as well display aggressive behaviour towards themselves and others.

- Child abuse and physical punishment can produce feelings of guilt, violation, loss of control and lowered self- esteem.

- Children who are subject to physical and mental punishment commonly experience humiliation and shame.

- Punishment reinforces rebellion, resistance, revenge, uncertainty, resentment and an identity of failure.

- A common effect of corporal punishment is a growing fear of teachers among school children and therefore a dislike of school.

- Corporal punishment is a direct and significant reason for children dropping out of school.

- Children who are emotionally affected when others are beaten and humiliated in class may also refuse to return.

- Corporal punishment is not only physically painful; the children interviewed also said that other students made fun of them, making them feel "mentally bad".

- Even minor forms of violence can cause injuries, and in the worst case permanent disability and even death.

- Corporal punishment clearly reflects and manifests children's lack of power and their low social status within society, the family and in the class room.

- Corporal punishment tends to bring negativity and make the child resort to violence, the child could possibly use Corporal punishment in future date because of his $\backslash$ her past experiences.

- Corporal punishment developed rapidly in the $18^{\text {th }}$ century. In India nowadays many schools use corporal punishment as recognized law. Though Corporal punishment leads to negative behaviour among the students, many schools in India practice it as a recognized law.

\section{STATEMENT OF THE PROBLEM}

Children are beaten in their schools as a means of discipline. Corporal punishment means to inflict punishment on the body. It is to beat, hit, spank, swat, pinch or cane a child with belts, hands, sticks or any other tool. Such violence may be a deliberate act of punishment or simply 
the impulsive reaction of an irritated teacher, parent, adult or even an older child. The main aim of the study is to protect school children from corporal punishment and also create awareness programmes of corporal punishment among public. Hence, there is an imperative need to undertake a study of this nature to identify the problem and offer suitable solutions to overcome the problems identified.

\section{SCOPE OF THE STUDY}

Sivakasi is a popular Industrial town. Sivakasi is famous not only in India but also in the World for its industrial production of match works, fireworks and printing works. Our Late Prime Minister Pandit Jawaharlal Nehru called Sivakasi as "Mini Japan". Education plays an important role in the life of every human being. Education brings an all-round development of the personality. Its aim is to activate the individual in all spheres of social life. Education should develop a dialogical relation between the teacher and the taught. Education facilitates employment to the educated. The present study focuses mainly on the problems of school children. The study also concentrates on the attitude of the teachers towards the Corporal Punishment in and around Sivakasi.

\section{OBJECTIVES OF THE STUDY}

- To analyze the various types of Corporal Punishment.

- To review the Corporal punishment practiced in Schools.

- To ascertain the opinion of the students about Corporal Punishment.

- To analyze the attitude of the teachers towards Corporal Punishment in and around Sivakasi Schools.

- To suggest appropriate measures to overcome the various problems of Corporal Punishment.

\section{SUGGESTIONS AND RECOMMENDATIONS}

After going through the above facts and findings the researcher has preferred to provide the following suggestions and recommendations to abolish corporal punishment in schools in the study area.

\section{FROM THE STUDENTS POINT OF VIEW}

- Now -a -days we find the children to be very sensitive in all aspects of life and hence violence is not the answer to deal with their problem. The proverb "spare the rod and spoil the child" seems to be losing its ground nowadays.

- The age in which we live today is the age of reform and hence corporal punishment seems to be irrelevant in the present age.

- New laws are to be introduced to ban the corporal punishment totally.

- Parents too have a special role in moulding the character of their children. The child should be exposed to all kinds of experiences and he/she should be trained in the art of decision making skill. 
- Educational departments support the fundamental rule which does not allow corporal punishment. Hence it is that corporal punishment is otherwise not advisable.

- Corporal punishment is not merely ineffective but also makes children defiant, rebellious and hostile. They can develop a warped personality; can become spouse beaters, molesters, and rapists. They begin to believe that might is right, and that violence is the only answer to most problems. Hence it is recommended that every child should be given an opportunity to learn from error of his/ her ways through corrective measures.

- Corporal punishment is a cycle of child abuse. It teaches children to hit someone smaller and weaker. To ensure school discipline appropriate measures should be administered in a manner consistent with the Childs human dignity.

- Corporal punishment is often not used as a last resort. It is often the first resort for minor misbehaviours. It makes the child to behave with negative attitude. There are many alternatives to corporal punishment and they contribute positive behaviours among students such as Parent Teachers Association, instructions to all students.

- Issuing of transfer Certificate for simple reasons should be avoided. School authorities should be more considerate towards students and should not be bureaucratic and rigid.

- The state government should review the existing laws to ensure the effective prohibition of corporal punishment and other inhuman and degrading treatment in the schools.

- As a child he/ she has the right to have knowledge about the child rights. Hence awareness programmes on the child rights should be conducted among the children.

- Parent teachers' meeting is to be arranged periodically to bring collective representation in order to avoid isolated vindictive actions. It must be made mandatory for the school management to convene parent teachers meeting regularly to discuss such issues.

- Child rights committees also play a role in checking the physical assaults made on the students in schools for trivial reasons.

- To bring "CHILD RIGHTS" with in the school curriculum, in particular the right to physical integrity and protection from all forms of violence.

- Apply rules consistently.

\section{FROM THE TEACHERS POINT OF VIEW}

- Crowded classrooms with inadequate infrastructure, insufficient learning tools lead to corporal punishment. Hence the government as well as school management should take steps to improve the infrastructure in the schools and encourage teachers to facilitate active learning technique.

- Ensure teachers and school leaders to receive In-service training on child rights, specifically the right to physical integrity and human dignity, and on alternative methods to corporal punishment.

- As the teachers are ill-trained and under paid it lead to use of corporal punishment. So the school management should appoint well qualified teachers by dumping the bad ones, paying the good ones negotiable salary.

- To develop pro-social behaviour, self-discipline and good character among the students.

- Teachers should maintain friendly relations with students and give a chance to them to express their views in the class room regarding their subjects of study. 
- To use positive rather than negative punishments like conferences with students for planning acceptable behaviour, advising and counseling. Many alternatives to corporal punishment have proven their worth.

- To arrange tutorial meetings in school once in a month.

\section{CONCLUSION}

Corporal punishment is not at all applicable in today's modern world of reform, it tends to bring negativity and makes the child to resort to violence, the child could possibly use corporal punishment in future date because of his/ her past experience. There are many other ways to bring up a child understand and value human life and dignity making him/or her better individuals and humans and better citizens. Corporal punishment though may sound like a better alternative and the last resort to inflict punishment but it is highly advisable not to use it either at homes or schools, there are instances to show that it has a far reaching bad effect upon the students because there has been many deaths (suicide) in the past due to the use of corporal punishment. So the government and the school management should take a strong stand through the application of strict legislations \& rules to prevent its use and it should also be wiped off completely from schools.

\section{REFERENCE}

[1] Aadesh, K Devan., "Crime against women and child”, cyber tech publications, New Delhi, 2008.

[2] Dass, N.P., "Child development and welfare service”, Smit enterprises, New Delhi, 2007.

[3] Gopal Krishnan, B., "Rights of children”, Aavishkar publishers, Jaipur, 2004.

[4] Jyostna Tiwari., "Child abuse and human rights", vol I, Chaula offset press, Delhi 2005.

[5] Dinamalar, 1st march, 2009.

[6] Manitha Urimai Kangani, Page 24- 26, Nov 2008.

[7] The Modern Medical Encyclopedia, page 266-267

[8] The World Book Encyclopedia, vol III

[9] WWW. End corporal punishment.org

[10] WWW.Hindu.com

[11] WWW. Manitham.net

[12] WWW. Stophitting.com

[13] WWW. Unicef.org 